\title{
Multifunctional Role of Integrated Farming System in Developing Countries
}

\author{
Purnabha Dasgupta ${ }^{1}$, Rupak Goswami ${ }^{1}$, Md Nasim Ali $^{1 *}$, Somsubhra Chakraborty ${ }^{1}$ and Subhrajit K. Saha ${ }^{3}$ \\ ${ }^{1}$ Integrated Rural Development and Management Faculty Centre, Ramakrishna Mission Vivekananda University, \\ Narendrapur, West Bengal (711 202), India \\ ${ }^{2}$ Dept. of Soil Science and Agricultural Chemistry, UBKV, Cooch Behar, West Bengal (736 165), India \\ ${ }^{3}$ Dept. of Biology, Georgia Southern University, Statesboro, GA (30 458), United States
}

\section{Article History}

Manuscript No. AR972

Received in $15^{\text {th }}$ October, 2014

Received in revised form $15^{\text {th }}$ May, 2015

Accepted in final form $5^{\text {th }}$ June, 2015

\section{Correspondence to}

*E-mail: nasimali2007@gmail.com

\section{Keywords}

Integrated farming, stress management, multifunctional agriculture, agro-ecological practices

\begin{abstract}
Agro-ecological practices, including integration within farming systems, have increasingly been acknowledged as key development alternative to safeguard rural people's basic needs. It also enhances farmers' socio-ecological capacities to sustain livelihoods. This paper explores the multidimensional nature of agro-ecological practices and takes stock of its multiple outcomes in smallholder systems of developing countries. Literatures suggest that farmers' foremost concern is to meet their socio-economic, cultural and ecological needs in addition to combating multiple adversities caused by biotic and abiotic stresses. This asks for planned integration among the components in small farms leading to reduced stress and multiple benefits to the farm households. Integration among the components of farming system are often employed as a livelihood strategy in small farms and it plays a pivotal role in meeting the multidimensional needs of the farm family such as food security, risk reduction, income and employment, biodiversity, carbon storage and energy efficiency in farm. Public extension must appreciate IFS as a socio-ecological intervention, instead of a technology, to achieve varied desirable socio-economic-ecological outcomes.
\end{abstract}

\section{Introduction}

Ensuring food, nutrition and livelihood security through agriculture without causing negative externalities on social, economic and environmental sustainability is a challenge to agriculture and rural development in developing nations (Foley et al., 2011). This has become even more important in the context of ever increasing pressure on natural resources and globalization of agri-food chains (Koohafkan et al., 2012). In the face of encroachment of land for intensive agriculture, industrialization and urbanization in the first half of the $21^{\text {st }}$ century, both economic and natural resource policy now need to be interlinked with smallholder agriculture. The proposition is to promote sustainable farming systems for smallholders following agro-ecological principles as a poverty alleviation strategy.

During the height of Green Revolution and even after its illeffects started to prop up, the concept of integrated/bio-diverse/ agro-ecological farming received little attention worldwide, perhaps due to its presumed subsistence nature. In the early years of the new millennium, consensus started growing around the proposition that small family farms are going to play crucial role in shaping the future employment, energy demand and food sovereignty of the world (FAO, 2012). This is important, since the number of small and marginal farms is on the rise throughout the developing nations and many of them are leaving their ancestral vocations, since little incentive holds them back to farming. The situation becomes harsh in marginal and less integrated environments (rainfed, coastalsaline production systems), where most of the poor people live. Future of agriculture and rural poverty alleviation depends on how we ensure food, nutrition and livelihood security through sustainable and integrated family farming, which is resilient to uncertainties of open markets and climatic variability.

On the other hand, dealing with the challenges of repositioning agro-ecological perspectives for meeting multiple nutrition demand of households is crucial, especially in a period of what might be regarded as an era of agri-food 'productionism'. How can the world be fed in a sustainable way? Can sustainable farming systems of smallholders and their labor intensive practices contribute to an efficient, 
productive and profitable agriculture, meeting the growing food demands and acclimatizing to climatic changes? Can this new neo-Malthusian challenge be met by continued dependence on conventional agri-food production paradigm and packages of technologies associated with it? The challenge to increase food production is not only to feed consumers, but to maintain dietary balance also. In developing nations, with industrialization and commercialization of different production systems, people now have more expendable cash in hand to be spent on food posing challenge to the food production system aiming to meet socially acceptable and nutritionally appropriate demand for food (Cirera and Masset, 2010). Thus, food demands will both grow and shift in the coming decades not only as a result of population growth but also due to the uneven economic growth of consumers, growing urbanization encouraging people to adopt new diets, and climatic variations threatening both land and water resources (Pretty et al., 2006). Predictions of future food demand also differ, but even the most optimistic scenarios require increase in food production in tune of at least 50\% (The Royal Society, 2009).

The bottom line is very clear-agriculture in smallholder systems needs to be resilient and sustainable, and at the same time yield multiple benefits to the smallholders including the futuristic provisions for eco-system services. Integration and diversification in the small and marginal farms can address many of these burgeoning challenges. Integrated Farming Systems (IFS) employ a unique resource management strategy to help achieving economic benefit and sustain agricultural production without undermining the resource base and environmental quality. Due to various reasons, such as decreasing farm income, reduced soil fertility, market demand, climatic variability, employing family labour etc., farmers of complex agro-ecosystems have developed some unique integrated farming systems, which are resilient to such multiple changes. Many NGOs have also worked with the communities to promote and improve such systems. Investing in such farming ensures that the growth in agriculture is inclusive, pro-poor, and environmentally sustainable (Altieri, 2002) and this can also be the most effective route to bring about economic growth and poverty reduction, with enhanced resilience of small farmers to disasters (Altieri et al., 2012). This is particularly important since sustainable intensification of small farms is now considered to be of critical need for feeding the future generation (Godfray et al., 2010; Tilman et al., 2011). It is time to reckon these integrated systems as units of planning for effective natural resource management.

\section{The Context of Agro-ecological Agriculture in Developing Nations}

Throughout the developing world resource poor farmers comprises more than $90 \%$ of the total farmer population located in risk-prone, marginal environment with minimum resources to survive (Altieri, 2002). In contrast, with the rapid growth of urbanization, requirement for unskilled laborers in cities have grown sharply. Literally, these cities engulfed all the unskilled labor force as daily wage labour. Many of them are small and marginal resource-poor family farmers. These farmers silently lose their identity, expertise, are exposed to different socio-biological vulnerabilities and gradually become an insecure vulnerable group. Public extension, backstopped with strong policy will, has tried to thwart this trend, especially when driving out of smallholders from rural setting is largely involuntary. Recently, many of these landless or marginal landholder farmers have started coming back to farming after experiencing the trap of urban insecurity and realizing the potential of sustenance with diversified small farm produces. As a result, the pace of reverse migration become faster and people realized that small farms, if managed judicially, can produce enough for their sustenance (Cirera and Masset, 2010).

Moreover, with rapid development of infrastructural facilities, particularly metal roads, electricity, and telecommunication, cities came closer to the rural areas and rural people suddenly got the opportunity to reach larger urban markets. Most importantly, resource poor farmers of these regions are exposed to the global market challenge, resource rich farmers from developed nations being the obvious competitors (Altieri et al., 2012). The resource poor farmers of developing nations now realized the importance of efficient natural resource management to maintain food and nutritional security on one hand and to compete in the larger agri-food market on the other. From their experiences farmers also realized that demand of the nearby cities is multidimensional as the city dwellers have more money to spend for their food. This gave rise to the demand of protein based food items and high value vegetables (Benton et al., 2003). The context has encouraged the idea of using one piece of land for multiple purposes by resource poor farmers in developing nations, which has often taken form of what we call integrated farms.

\section{Integration in Farming Systems as a Stress Management Strategy}

When a farmer takes decision on making integration between different components in a farming system, it is guided either by the socio-economic gain or expectation of maximum output from limited input or an urge to minimize agro-ecological stress. Especially, in stressed ecosystems, the farmers often integrate components in a farming system to avoid risks of crop loss, food insecurity, loss of livestock etc. Past experiences of climatic/ecological hazards also play crucial role in the 
decisions of making integration in farms, e.g. draught-like situation in the previous year may force the farm family to keep less number of livestock this summer or sudden increase in water availability may push them to keep more livestock than previous year. In fact, a number of such strategies have been developed by the farmers to adapt climatic variation, often using local knowledge (Dutta et al., 2013). Hence, natural process of integration in the farm is more of an adaptive strategy rather than a technical intervention being taken place in logical vacuum. Figure 1 describes a simplified relationship between biotic and abiotic stress in a farm with integration in its farming systems.

In rural areas, livelihood is structured and restructured by agriculture and allied activities in a multitude of ways. Numerous factors, such as geo-physical properties, sociopolitico-cultural atmosphere, techno-economic conditions etc. integrate different enterprises in the farm and shape people's livelihood (Chambers and Conway, 1992). The stress might be biotic (pest infestation, biodiversity loss in flora and fauna) or abiotic (extreme climatic events, salinity, inundation) in nature. These stresses are again outcomes of anthropogenic activities, policy initiatives, climate etc. There might be other factors, such as market, consumer choice, local culture and food habit, fragmentation of farmland and local labour market. These factors are outcomes of complex socio-politico-economic context defined by economic liberalization, urbanization, land grabbing, and shift of livelihoods from farm-to non-farm sectors. These factors hierarchically and collectively affect farm-level integration in smallholder systems. The integration may take the form of enterprise combinations, land shaping, mixed and multiple cropping to ensure biomass use for nutrient and pest management, provisioning of water in lean months, use of aerial spaces to mention a few. Stresses construct people's mindset to face odds in choosing different diversified methods of agricultural practices to tackle the stress condition. Thus, people's strategies to fight with adverse conditions are either set by the natural courses or by some other anthropogenic realities (Adato et al., 2003). Hence, the basic purpose of choosing different mechanism to integrate in farms rests on the fact and degree of biotic and abiotic stresses faced by the farmers (De Buck et al., 2001).

\section{Multifunctional Benefits of Integration in Farming System}

The concept of 'agricultural multifunctionality' originated in the Western European context of rural development, where policy focus shifted from food and fiber production to a comprehensive inclusion of multifunctional goals in agriculture. This entailed reconsideration of the role of small family farms, especially to improve food safety, amenities and landscapes, and protecting the environment (Van Huylenbroeck, 2002). Sustainable agriculture in developing countries emphasizes food security and sustainability of smallholder farmer livelihoods, as opposed to food safety and convenience for consumer livelihoods and environmental protection in developed countries (Amekawa et al., 2010). That is why the role of multifunctional agriculture in this article must be appreciated within the context of smallholders of developing countries. Although there might be numerous multifunctional benefits of IFS, we have taken up six among them-one economic (income), two social (food security and gender) and three environmental (carbon storage, biodiversity and energy efficiency) for the present article.

\subsection{Integrated farming system and farm income}

IFS is reported to fetch higher farm income and profitability than conventional farming in smallholder systems of developing world (Edwards, 1989; Behera and Mahapatra, 1999; Routaray et al., 2005; Tipraqsa et al., 2007). By increasing the provision of animals and fish, IFS generates higher cash income. It is also reported to achieve low cost of production and thus increase farmer's net income without disturbing the productivity concern. Since it adds to the sustainability of the system (by ensuring local sourcing of agricultural inputs), the income from IFS is expected to be stable over years. Hence, IFS may break the subsistence blockade for many marginal farmers and help in maintaining investment in regional agriculture. The components in an IFS greatly determine the extent of farm income, its stability and equitable distribution across seasons. Crop-livestock-fish system or crop-livestock system is reported to give higher net return than crop-based systems alone (Ugwumba et al., 2010; Desai et al., 2013). However, the amount of income is difficult to be interpreted due to the variation in space and time. Reports in Indian context in the last ten years suggest an income range of ₹ 55,000 annum ${ }^{-1}$ (Ramrao et al., 2005) to ₹ 80000 annum $^{-1}$ (Dasgupta et al., 2014). Nevertheless, a sound meta-analysis would have given a better estimate of the gross return from IFS. Apart from increasing the farm production, IFS even out the risks and uncertainties of income from conventional cropping and reduces the time lag between investment and returns. Regular and evenly distributed income throughout the year render the farm resilient to uncertainties and reduces vulnerability against climatic and market variations (Pretty, 1997).

\subsection{Integrated farming system and food security}

Among the major challenges the world faces today, the urgency of providing food security to the growing human population and slowing down the quick loss of irreplaceable biological diversity appear most prominent (Chappell and La Valle, 2011). Global food security scenario is insufficient to guarantee 


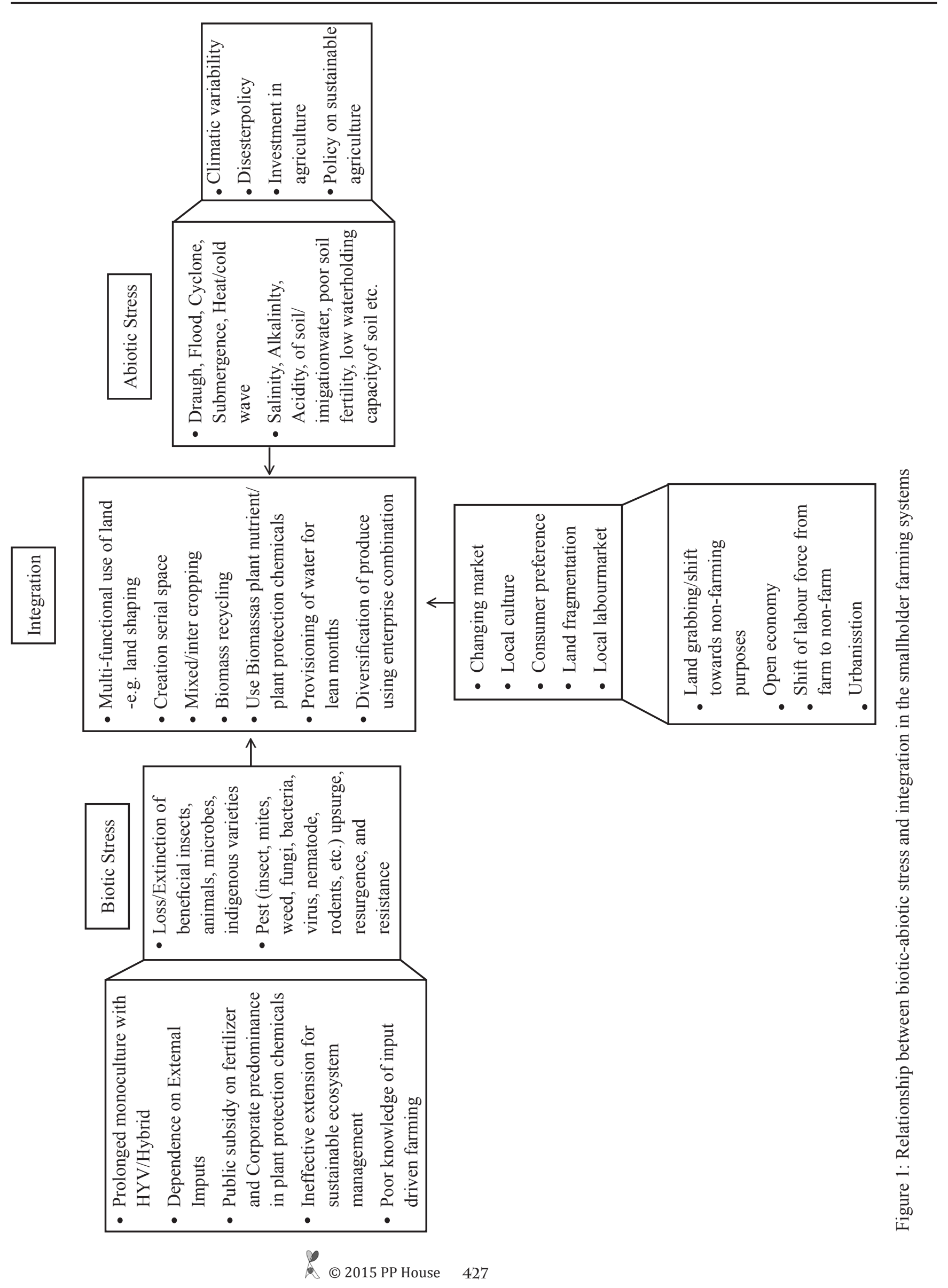


food security at different scales (i.e., on a national, local, or individual basis) and this inability to generate sufficient food globally means that some or all regions of the world needs to overcome food insecurity for its marginalised people (Rosset, 1999). Current food production systems upholds preference for industrialized high-input, high-yielding practices to traditional indigenous agricultural systems developed and practiced for thousands of years (Altieri, 1999; Netting, 1993; Rosset, 1999). Current food production systems upholds preference for industrialized high-input, high-yielding practices to traditional indigenous agricultural systems developed and practiced for thousands of years (Altieri, 1999; Netting, 1993; Rosset, 1999). These traditional systems have shown ability and promises to ensure household food security in developing countries. Since the concept of food security is understood as the availability of sufficient, safe and nutritious foods for all the members of a community all the time for leading a healthy and active life (Pinstrup-Andersen, 2009), one needs to go beyond the focus of food production only. IFS, often developed traditionally, maintain productivity of the farm, the availability of diverse food items throughout the year so that all members of the household are fed sustainably. Even if we measure food security by dietary diversity (Altieri, 2000), apart from the predominant energy intake approach, IFS would provide better food diversity than conventional farming. In that sense, IFS addressed the issue of food security in a holistic manner.

IFS results in improved household food consumption (Prein and Ahmed, 2000), especially for the vulnerable family members (children, pregnant/lactating women, and diseased) through provisioning of animal proteins and vegetable/fruits. Although empirical account of food intake in IFS is not very common, it is reported to increase food security in wide contexts (Alam, 1997; Mula and Sarkar, 2013). Indirectly, improved income naturally contributes to higher food consumption and food security (Al Mamun et al., 2012). Nevertheless, there is a serious literature gap in food security measurement (calorific or interview based) in integrated farming systems and its comparison with competitive land use systems.

\subsection{Integrated farming system, employment opportunity and gender role}

Some authors have summarized the multifaceted benefits of IFS to include economic benefits in terms of increased food production, and social benefits in terms of provision of employment opportunities for excess labour force heading towards the urban areas (Ugwumba, 2010). IFS is labour intensive, which creates on-farm employment and most of the labour required in the production process is contributed by the farmer and his family members. IFS is reported to generate more man-days in the farm itself than conventional farming (Tipraqsa et al., 2007), the figures although varying widely across systems. Where Behera et al. (1999) reported more than 450 man-days ha $^{-1}$ year ${ }^{-1}$ in a pond-based integrated farming system, Jayanthi et al. (2003), Ramrao et al. (2005) and Solaiappan et al. (2007) reported 575,950 and 343 mandays ha $^{-1}$ year $^{-1}$ respectively in mixed integrated systems. Although, adjustment for inflation is required for comparing such reports, there is no systematic meta-analysis addressing this issue. Apart from generating man-days, IFS ensures that the employment is generated throughout the year, ensuring a steady sink for local labour force.

Since the male members of the households are often engaged in agricultural works in distance pieces of land, or migrate in lean agricultural months, women take care of many activities in IFS. With the increased integration in farms, women get more engaged in farming activities, especially in home based income generating activities. Women are mostly found to perform-poultry rearing, cattle rearing, milch cow rearing, Goat/sheep rearing, sewing, vegetable production, vegetable selling, and nursery reforestation (Sharmin et al., 2012). Both access and control over the farm resources increase for farm women (Setboosarng, 2002). Since many of the resources (such as fodder, chicken egg) are produced within the farm, women do not have to travel to collect those resources elsewhere. Many of the farm outputs are also sold in local markets by the women rendering some cash income at their disposal (Goswami and Dasgupta, 2014).

\subsection{Integrated farming system and energy efficiency}

Increased use of nitrogenous fertilizers, pumped irrigation and mechanical power, which are particularly energy-intensive, has rendered industrialised agriculture progressively less energy efficient (Pretty, 2002). These three sources account for more than $90 \%$ of the total direct and indirect energy inputs to farming (Leach, 1992). The crop yield is a function of energy input. Depending on the environmental conditions, crops convert only $0.5-5 \%$ of the photosynthetic active radiation into biomass (Hulsbergen et al., 2001). Direct energy is required to perform various tasks related to crop production processes such as land preparation, irrigation, harvest, postharvest processing, transportation of agricultural inputs and outputs. In other word, direct energy includes fuel and electricity which are directly used at farm (Hulsbergen et al., 2001). Indirect energy is not directly consumed in the farm but used in the manufacture, packaging and transport of fertilizers, seeds, machinery production and pesticides (Ozkan et al., 2004). In developing countries, major sources of farm energy expenditure are fertilizer, and farm machinery. Since integrated farms are relatively less mechanized and encourages the use of internal inputs (instead of using external farm inputs such as fertilizers), energy use is much lower in integrated farms compared to conventional farms. Integrated farms (a form of sustainable 
farming) are mostly found in smaller farms, which have higher energy efficiency in general (Pretty, 1995). Moreover, many of these integrated farms are subsistence and involve less mobility in and around the farm, thus saving human energy and energy associated with transportation of farm produce.

Low-input rice in Bangladesh, China, and Latin America is some 15-25 times more energy efficient than irrigated rice grown in the USA (Pretty, 2002). Empirical evidences different parts of the globe suggest that integrated system is the most efficient in terms of energy efficiency (Bailey et al., 2003; Alluvione et al., 2011) and this input output ratio of energy varies greatly in different systems. Deike et al. (2008) observed a ratio of 15-17 in European context, where Channabasavanna et al. (2010) reports a ratio of 6.40 in southern India. If the systems are organic in nature, energy ratio is expected to improve further. These values have great significance for exante assessment of integrated farming systems, especially when we are interested to introduce or shift to newer agricultural systems.

\subsection{Integrated farming system and carbon storage}

Carbon sequestration is defined as the capture and secure storage of carbon that would otherwise be emitted to or remain in the atmosphere (FAO, 2000). Agricultural systems contribute to carbon emissions through direct use of fossil fuels in farm operations (Lal, 2004), indirect use of embodied energy in inputs that are energy-intensive to manufacture (particularly fertilizers) (Lal, 2004) and cultivation of soils resulting in the loss of soil organic matter (Starritt, 2010). IFS has a tremendous potential of storing Carbon in the eco-system since-(a) tree is considered as an important component of the system, (b) livestock are raised and organic manures are used extensively in farming that enhances soil carbon storage, (c) external input like fertilizers are minimized hence indirectly saving fossil fuel, and (d) little amount of fossil fuel is used in farming. Since monetary payment of ecosystem services (such as carbon credit) is not common in many developing nations, the economic benefit of carbon storage has not yet been explored for integrated smallholder farms. However, this might prove to be an important source of cash income for farms maintaining multipurpose tree species and biomass recycling for long periods.

There is little specific empirical evidence on carbon storage in integrated farming system, especially in smallholder context. However, extensive study is reported in different agricultural systems or land use systems. Carbon storage in Agro-forestry systems vis-a-vis Home garden systems is well recorded (Roshetko et al., 2002; Albrecht and Kandji, 2003; Henry et al., 2009). Smallholders across the developing world maintain tree species in their farms and these often play a critical binding agent in farm-level sustainability (Preston, 1992), which is expected to store carbon within small farms for longer period. Available review (Albrecht and Kandji, 2003) suggest wide range of $\mathrm{C}$ storage potential ( $\left.\mathrm{MgC} \mathrm{Cha}^{-1}\right)$ across the globe: 29-53, 39-102, 28-51, 133-154 and 15-18 Mg C ha- ${ }^{-1}$ for Africa (Agrosilvicutural), South America (Agro-silvicutural), Australia (Silvi-pastoral), North America (Silvi-pastoral) and Northern Asia (Silvi-pastoral) respectively. The agro-silvicultural system in Southeast Asia itself shows a wide variation of $\mathrm{C}$ storage potential, 12-228 Mg C ha-1. Since, tree species in the farms of marginal farmers in India do not follow any systematic pattern (such as alley cropping, annual crop-tree combination, multi-strata agroforestry), extrapolating the recorded carbon storage potential from one agricultural system is prone to over or underestimation.

\subsection{Integrated farming system and biodiversity}

A consistent side effect of agricultural expansion and intensification is fragmentation and isolation of natural habitats rendering them unsuitable place for many species (Donald et al., 2001). Biodiversity attributes, such as species composition, community structure, population dynamics, behaviour, breeding success, and individual fitness are negatively affected by most of the human managed agricultural systems (da Silva and Pontes, 2008). Alternative agricultural systems such as sustainable integrated farming systems are reported to reverse such undesirable trends of biodiversity depletion (Bengtsson et al., 2005). Diversity of plants and livestock used in agricultural production maintain the balance of agro-ecosystem within which recycling of resources takes place to satisfy the need of farm households. Moreover, dependence on a limited number of varieties and breeds enhances their susceptibility to pests and diseases (Hayati et al., 2006). IFS encourage the maintenance of biodiversity in the agro-ecosystem by growing more number of crops/varieties (often by employing mixed and intercropping), by raising more number and breed of ruminants and non-ruminants in the farm, by maintaining several tree species, shrubs and herbs in the homestead and farm (to meet several household and farm-related needs), by encouraging the integrated management of pest and by enhancing soil microbial biodiversity by incorporating more organic matter into it.

Although biodiversity measurement has been widely undertaken in different agricultural systems (Williams, 2004), its measurements are relatively sporadic for integrated systems (e.g. measurements are available for crop-crop/croplivestock/crop-aquaculture systems). Moreover, studies vary in their measurement focus also; some focusing on plant/tree species diversity, other on animal or microbial diversity. In agroforestry systems, Mukul (2014) reports Shannon-Weiner biodiversity index in the range of 2.85-3.29 and Bardhan et al. (2011) reports a value of 3.5. Bhagwat et al. (2008), in a global review, reported species richness of 20-186 for animals, 
44-250 for insects, 25-144 for lower plants and 8-213 for tree. In another integrated land use system, homestead system, Shannon-Weiner biodiversity index is reported to be 2.2 and 3.21 in south Indian and West European context (Shastri, 2002). However, we do not have any detailed report on such statistics for integrated farming systems, particularly in Indian context.

Overall, the evidence till date strongly proposes that both biodiversity management and food security can be effectively addressed using alternative agricultural practices (Altieri, 2002). The majority of food insecurity at present is caused not by lack of food availability or insufficient agricultural production, but due to lack of sustainable form of resource base to the producers. Alternative agriculture in the form of integrated farming seems to be capable of producing sufficient yields by maintaining crop-livestock diversities and manage equitable socio-economic access outcome to the poorest section of the society (FAO, 2000). The evidence also supports the intuitive conclusion that integrated farming systems, which is generally targeted at sustainability of food production and compatibility with biodiversity conservation, is indeed better for sustainability of the socio-ecological process than conventional agriculture (FAO, 2012). In case of smallholder farmers, maintaining those differences are even more critical as they have little social status and poor access to natural resources. Thus, integrated farming system, being a proper multidimensional and sequential process, can meet the challenge of both diversified food demand of the farm families with relatively low external-input, and can manage the negative externalities of farming by producing multiple ecological services (Hazell and Wood, 2008).

\section{Conclusion}

IFS is capable of producing diverse social, economic and environmental benefits to the smallholder systems. It sustains smallholders in farming, reduces their vulnerability, ensures food security, employment opportunity, increases biodiversity, carbon stock in farm and improves energy efficiency of farming. Public extension must view IFS as a flexible socioecological intervention instead of a technology with varied desirable socio-economic-ecological outcomes. This will ask for appreciating its multifunctional role and designing of flexible farming systems in a demand-driven and locationspecific manner.

\section{References}

Adato, M., Meinzen D., Suseela, R., 2003. Assessing the impact of agricultural research on poverty and livelihoods. Quarterly Journal of International Agriculture 42(2), 149-167.
Al Mamun, S., Nasrat, F., Debi, M.R., 2012. Integrated Farming System: Prospects in Bangladesh. Environmental Science and Natural Resources 4(2), 127-136.

Alam J., 1997. Impact of smallholder livestock project in some selected areas of rural Bangladesh, Livestock Research for Rural Development 9 (3), 1-14.

Albrecht, A., Kandji, S.T., 2003. Carbon sequestration in tropical agroforestry systems. Agriculture, Ecosystems and Environment 99(1), 15-27.

Alluvione, F., Moretti, B., Sacco, D., Grignani, C., 2011. Energy Use Efficiency of cropping systems for a sustainable agriculture. Energy 36(7), 4468-4481.

Altieri, M.A., 1999. The ecological role of biodiversity in agroecosystems. Agriculture, Ecosystems and Environment 74(1), 19-31.

Altieri, M.A., 2000. Multifunctional dimensions of ecologicallybased agriculture in Latin America. The International Journal of Sustainable Development and World Ecology $7(1), 62-75$.

Altieri, M.A., 2002. Agro-ecology: the science of natural resource management for poor farmers in marginal environments. Agriculture, Ecosystems and Environment 93(1), 1-24.

Altieri, M.A., Funes-Monzote, F.R., Petersen, P., 2012. Agroecologically efficient agricultural systems for smallholder farmers: contributions to food sovereignty. Agronomy for Sustainable Development 32(1), 1-13.

Amekawa, Y., Sseguya, H., Onzere, S., Carranza, I., 2010. Delineating the multifunctional role of Agro-ecological practices: toward sustainable livelihoods for smallholder farmers in developing countries. Journal of Sustainable Agriculture 34(2), 202-228.

Bailey, A.P., Basford, W.D., Penlington, N., Park, J.R., Keatinge, J.D.H., Rehman, T., Yates, C.M., 2003. A comparison of energy use in conventional and integrated arable farming systems in the UK. Agriculture, Ecosystems and Environment 97(1), 241-253.

Bardhan, S., Jose, S., Biswas, S., Kabir, K., Rogers, W., 2012. Home garden agroforestry systems: an intermediary for biodiversity conservation in Bangladesh. Agroforestry Systems 85(1), 29-34.

Behera, U.K., Mahapatra, I.C., 1999. Income and employment generation for small and marginal farmers through integrated farming systems. Indian Journal of Agronomy 44(3), 431-439.

Bengtsson, J., Ahnström, J., Weibull, A.C., 2005. The effects of organic agriculture on biodiversity and abundance: a meta-analysis. Journal of Applied Ecology 42(2), 261269.

Benton, T.G., Vickery, J.A., Wilson, J.S., 2003. Farmland biodiversity: is habitat heterogeneity the key? Trends in 
Ecology and Evolution. 18(4), 182-188.

Bhagwat, S.A., Willis, K.J., Birks, H.J.B., Whittaker, R.J., 2008. Agroforestry: a refuge for tropical biodiversity? Trends in Ecology and Evolution 23(5), 261-267.

Chambers, R., Conway, G., 1992. Sustainable rural livelihoods: practical concepts for the 21 st century. Institute of Development Studies, Sussex, UK. Available from http://opendocs.ids.ac.uk/opendocs/bitstream/ handle/123456789/775/Dp296.pdf?seq. Accessed in December 2014.

Channabasavanna, A.S., Biradar, D.P., Prabhudev, K.N., Hegde, M., 2010. Development of profitable integrated farming system model for small and medium farmers of Tungabhadra project area of Karnataka. Karnataka Journal of Agricultural Sciences 22(1), 25-27.

Chappell, M.J., La Valle, L.A., 2011. Food security and biodiversity: can we have both? An Agro-ecological analysis. Agriculture and Human Values 28(1), 3-26.

Cirera, X., Masset E., 2010. Income distribution trends and future food demand. Philosophical Transactions of the Royal Society B: Biological Sciences 365, 2821-2834.

da Silva Jr, A.P., Pontes, A.R.M., 2008. The effect of a megafragmentation process on large mammal assemblages in the highly-threatened Pernambuco Endemism Centre, north-eastern Brazil. Biodiversity and Conservation 17(6), 1455-1464.

Dasgupta, P., Goswami, R., Ali, M.N., Biswas, S., Saha, S.K., 2014. Bio-diverse integrated farms. LEISA India 16(2), 20-23.

De Buck, A.J., Van Rijn, I., Roling, N.G., Wossink, G.A.A., 2001. Farmers' reasons for changing or not changing to more sustainable practices: an exploratory study of arable farming in the Netherlands. The Journal of Agricultural Education and Extension 7(3), 153-166.

Deike, S., Pallutt, B., Christen, O., 2008. Investigations on the energy efficiency of organic and integrated farming with specific emphasis on pesticide use intensity. European Journal of Agronomy 28(3), 461-470.

Desai, B.K., Rao, S., Biradar, S.A., Prahlad, U., Shashikumar, M., Santhosh, U.N., 2013. Development of Profitable Integrated Farming Systems for Small and Marginal Farmers of Hyderabad Karnataka Region under Irrigated Condition. International Journal of Agriculture, Environment and Biotechnology 6(4), 617-622.

Donald, P.F., Green, R.E., Heath, M.F., 2001. Agricultural intensification and the collapse of Europe's farmland bird populations. In: Proceedings of the Royal Society of London B, 268(1462), 25-29.

Dutta, A., Goswami, R., Dasgupta, D., 2013. Indigenous knowledge base in coastal agro-ecosystem of West Bengal, India. In: Dasgupta, D. (Ed.), Indigenous
Knowledge for Food and Nutritional Security. Agrobios, Jodhpur, 344-354.

Edwards, C.A., 1989. The importance of integration in sustainable agricultural systems. Agriculture, Ecosystems and Environment 27(1), 25-35.

FAO, 2000. Carbon sequestration options under the clean development mechanism to address land degradation. FAO, Rome. Available from http://www.fao.org/ forestry/15528-0534f06d08a9c3cbcd73deefd8d06c67 4.pdf. Accessed in March 2015.

FAO, 2012. The State of Food Insecurity in the World 2012. FAO, Rome. Available from http://www.fao.org/ docrep/016/i3027e/i3027e.pdf. Accessed in January 2015.

Foley, J.A., Ramankutty, N., Brauman, K.A., Cassidy, E.S., Gerber, J.S., Johnston, M., Zaks, D. P., 2011. Solutions for a cultivated planet. Nature 478(7369), 337-342.

Godfray, H.C.J., Beddington, J.R., Crute, I.R., Haddad, L., Lawrence, D., Muir, J.F., Toulmin, C., 2010. Food security: the challenge of feeding 9 billion people. Science 327(5967), 812-818.

Goswami, R., Dasgupta, P. (2014). Integrated farming system and sustainability of agriculture: Case of integrated farms of Sunderbans. In: Dasgupta, D. (Ed.), Frontiers of Rural Development. Vol. I. Agrobios, Jodhpur, 127-139.

Hayati, D., Karami, E., Slee, B., 2006. Combining qualitative and quantitative methods in the measurement of rural poverty: the case of Iran. Social Indicators Research 75(3), 361-394.

Hazell P., Wood, S., 2008. Drivers of change in global agriculture. Philosophical Transactions of the Royal Society B: Biological Sciences 363(1491), 495-515.

Henry, M., Tittonell, P., Manlay, R.J., Bernoux, M., Albrecht, A., Vanlauwe, B., 2009. Biodiversity, carbon stocks and sequestration potential in aboveground biomass in smallholder farming systems of western Kenya. Agriculture, Ecosystems and Environment 129(1), 238252.

Hulsbergen, K.J., Feil, B., Biermann, S., Rathke, G.W., Kalk, W.D., Diepenbrock, W.A., 2001. Method of energy balancing in crop production and its application in a long term fertilizer trial. Agriculture, Ecosystems and Environment 86, 303-321.

Koohafkan, P., Altieri, M.A., Gimenez, E.H. 2012. Green agriculture: foundations for biodiverse, resilient and productive agricultural systems. International Journal of Agricultural Sustainability 10(1), 61-75.

Lal, R., 2004. Soil carbon sequestration impacts on global climate change and food security. Science 304(5677), 1623-1627.

Leach, G., 1992. The energy transition. Energy Policy 20(2), 
116-123.

Mukul, S.A., 2014. Biodiversity conservation and ecosystem functions of traditional agroforestry systems: case study from three tribal communities in and around Lawachara National Park. In: Shaheed, M. and Chowdhury, H. (Eds.), Forest Conservation in Protected Areas of Bangladesh. Springer International Publishing, Switzerland, 171179.

Mula, G., Sarker, S.C., 2013. Impact of improved agrotechniques on sustainable livelihood empowerment: an economic study from West Bengal. Agricultural Economics Research Review 26, 129-137.

Netting, R., 1993. Smallholders, householders: farm families and the ecology of intensive, sustainable agriculture. Stanford, Stanford University Press, CA, USA. 58101.

Ozkan B., Akcaoz H., Fert C., 2004. Energy input output analysis in Turkish agriculture. Renewable Energy 29(1), 39-51.

Pinstrup-Andersen, P., 2009. Food security: definition and measurement. Food Security 1(1), 5-7.

Prein, M., Ahmed, M., 2000. Integration of aquaculture into smallholder farming systems for improved food security and household nutrition. Food and Nutrition Bulletin 21 (4), 466-471.

Preston, T.R., 1992. The role of multipurpose trees in integrated farming systems for the wet tropics. Legume trees and other fodder trees as protein source for livestock. FAO Animal Production and Health Paper 102, 193-209.

Pretty, J.N., 1995. Regenerating Agriculture: Policies and Practice for Sustainability and Self-Reliance. Earthscan, London, 61-63.

Pretty, J.N., 2002. Agri-culture: Reconnecting people, land, and nature. Earthscan, London, 68.

Pretty, J.N., Noble, A.D., Bossio, D., Dixon J., Hine R.E., Penning de Vries, F.W.T., Morison, J.I.L., 2006. Resource-conserving agriculture increases yields in developing countries. Environmental Science and Technology 40(4), 1114-1119.

Pretty, J., 1997. The sustainable intensification of agriculture: making the most of the land. The Land 1(1), 45-65.

Ramrao, W.Y., Tiwari, S.P., Singh, P., 2005. Crop-livestock integrated farming system for augmenting socioeconomic status of smallholder tribal of Chhattisgarh in central India. Livestock Research for Rural development. 18(7), Available from http://www.cipav.org.co/lrrd/ lrrd17/8/ramr17090.htm. Accessed in March, 2015.

Rautaray, S.K., Dash, P.C., Sinhababu, D.P., 2005. Increasing farm income through rice (Oryza sativa)-fish based integrated farming system in rainfed lowlands of Assam. Indian Journal of Agricultural Science 75(2), 79-82.
Roshetko, J.M., Delaney, M., Hairiah, K., Purnomosidhi, P., 2002. Carbon stocks in Indonesian homegarden systems: Can smallholder systems be targeted for increased carbon storage? American Journal of Alternative Agriculture 17(03), 138-148.

Rosset, P., 1999. The multiple functions and benefits of small farm agriculture in the context of global trade negotiations. Policy brief number 4: Development 42(2), 77-82.

Setboonsarng, S., 2002. Gender division of labour in integrated agriculture/aquaculture of Northeast Thailand. In: Edwards, P., Little, D.C., Demaine, H. (Eds.), Rural Aquaculture, CABI, UK, 253-274.

Sharmin, S., Islam, M.S., Hasan, M.K., 2012. Socioeconomic analysis of alternative farming systems in improving livelihood security of small farmers in selected areas of Bangladesh. The Agriculturists 10(1), 51-63.

Shastri, C.M., Bhat, D.M., Murali, K.S., Ravindranath, N.H., 2002. Tree species diversity in a village ecosystem in Uttara Kannada district in Western Ghats, Karnataka. Current Science 82(9), 1080-1084.

Solaiappan, U., Subramanian, V., Sankar, G.R., 2007. Selection of suitable integrated farming system model for rainfed semi-arid vertic inceptisols in Tamil Nadu. Indian Journal of Agronomy 52(3), 194-197.

The Royal Society, 2009. Reaping the Benefits; Science and the Sustainable Intensification of Global Agriculture. The Royal Society, London. Available from https:// royalsociety.org/ /media/Royal_Society_Content/ policy/publications/2009/4294967719.pdf. Accessed in December 2014.

Tilman, D., Balzer, C., Hill, J., Befort, B.L., 2011. Global food demand and the sustainable intensification of agriculture. Proceedings of the National Academy of Sciences 108(50), 20260-20264.

Tipraqsa, P., Craswell, E.T., Noble, A.D., Schmidt-Vogt, D., 2007. Resource integration for multiple benefits: multifunctionality of integrated farming systems in Northeast Thailand. Agricultural Systems 94(3), 694703.

Ugwumba, C.O.A., Okoh, R.N., Ike, P.C., Nnabuife, E.L.C., Orji, E.C., 2010. Integrated farming system and its effect on farm cash income in Awka south agricultural zone of Anambra state, Nigeria. American-Eurasian Journal Agricultural and Environmental Science 8(1), 1-6.

Van Huylenbroeck, G., 2002. Multifunctional agriculture: How to provide incentives to farmers? Paper presented at the 13th International IFM Congress Wageningen, The Netherlands, July 7-12, 2002.

Williams, J., 2004. Metrics for assessing the biodiversity values of fanning systems and agricultural landscapes. Pacific Conservation Biology 10(3), 145. 